\title{
Misuse of Shall in the English Translation of China's Legal Text
}

\author{
Jianjun Wang $^{1} \&$ Xi Chen ${ }^{2}$ \\ ${ }^{1}$ College of Foreign Languages, Inner Mongolia University, Hohhot, China \\ ${ }^{2}$ Department of Foreign Languages, Honder College, Inner Mongolia Normal University, Hohhot, China \\ *Corresponding author: College of Foreign Languages, Inner Mongolia University, Hohhot 010021, China. Tel: \\ 86-471-499-3241. E-mail: kingjjpt@163.com
}

Received: January 20, 2014 Accepted: February 25, $2014 \quad$ Online Published: March 13, 2014

doi:10.5430/wjel.v4n1p25 URL: http://dx.doi.org/10.5430/wjel.v4n1p25

\begin{abstract}
Shall is one of the most important words in legal English text, and is supposed to be used to impose a mandatory duty. However, in the translated English version of China's laws or statutes, shall is misused or overused. Some scholars have been suggesting that shall should be eliminated from legal English language, and replaced with other proper words, such as must. This paper studies the grammar relating to shall and misuse of shall in the translated English version of China's laws and statutes, and suggests that shall, as an important word in legal English vocabulary, should serve as the only means of imposing obligations on the subject capable of carrying out obligations.
\end{abstract}

Keywords: shall; misuse; obligation; English translation; China’s legal text

\section{Introduction}

In legal text, accuracy is a cardinal principle due to the fact that legal language is a normative language. A well-known scholar pointed out, "the competent draftsman makes sure that each recurring word or term has been used consistently. He carefully avoids using the same word or term in more than one sense ... In brief, he always expresses the same idea in the same way and always expresses different ideas differently.” (Dickerson, 1986, p.15) However, some translated English versions of China's laws and statutes don't accord with the "golden rule”, one example of which is the most-frequently-used word shall being overused and misused. Some English versions of China's laws and statutes are strewn with shall, which is definitely overused, or even misused. This paper discusses the use of shall in the English translation of China's laws and statutes, and tries to offer some suggestions on how to solve the problem of overuse and misuse of shall under such circumstances.

\section{Grammar Relating to Shall}

Shall is an auxiliary verb. It can also be a modal auxiliary verb, like can, may, must, and will. The modal auxiliary verbs are so called because they can function not only as auxiliaries (like be, do, have), but also can convey other meanings, including possibility (can / may), ability (can), permission (may), obligation (must / shall) and so on. As one of the modal auxiliary verbs, shall is defined in Oxford Advanced Learner's English-Chinese Dictionary (Hornby, 2004, p.1597) as follows:

i. $\quad$ used with $I$ and we for talking about or predicting the future.

(This time next week I shall be in Scotland.)

ii. used in questions with $I$ and we for making offers or suggestions or asking advice.

(Shall I send you the book?)

iii. (formal) used to show that you are determined.

(You shall succeed.) 
iv. (formal) used to give an order or instruction.

(Candidates shall remain in their seats until all the papers

have been collected.)

Some uses of shall have almost disappeared from current general usage, and shall is now only used with $I$ and we. In Oxford Advanced Learner's English-Chinese Dictionary, it is considered formal and old-fashioned that shall is used instead of will in modern English (Hornby, 2004, p.1597). However, shall is the most important word in law field, and helps to create a legal duty. Random House Webster's Dictionary of the Law defines shall as "expressing mandate, necessity or compulsion, especially in statutory or judicial directives.” (Xu, 2009, p.189). Black's Law Dictionary (Garner, 2004, p.1407) defines shall as follows:

i. has a duty to; more broadly, is required to: The requester shall send notice.

ii. should: All claimants shall request mediation.

iii. may: No person shall enter the building without first signing the roster.

iv. will (as a future tense verb): The corporation shall then have a period

of 30 days to object.

v. is entitled to: The general manager shall be reimbursed for all expenses.

Shall is of great importance in English versions of laws, statutes and regulations; however, to some extent, it is also the most overused and misused word in them. It is deemed by lawyers and draftsmen of laws that shall is the best word to impose a mandatory duty, and makes legal English documents professional. Consequently, shall is overused, or even misused in some translated English versions of China's laws and regulations. Shall has been used to do more than to express obligations in them.

\section{Disciplining the Use of Shall in Legal English Language}

Here is the actual situation in China: on the one hand, the translator is fascinated by the word - shall, so translated statutes exhibit overuse of the word (Chen, 2011, p.66). On the other hand, some scholars specializing in translation studies suggest that shall should be dropped from legal language due to its ambiguous meanings (Chen, 1992, p.19-20). The authors suggest that we should use shall to convey the meaning of obligation imposed on the subject of a sentence, which is the first meaning stated in Black's Law Dictionary. By doing so, we can clearly see who has the obligation or who has the duty.

For example:

Chinese text: 第四条 夫妻应当互相忠实, 互相尊重; 家庭成员间应当敬老爱幼, 互相帮助, 维护平等、 和睦、文明的婚姻家庭关系。(Article 4, Marriage Law of the People’s Republic of China)

English version: Article 4 Husband and wife shall be truthful to and respect each other. Family members shall respect the old, take good care of the underage, and help each other so as to maintain an equal, harmonious and cultured matrimonial and familial relationship.

In the above example, we can see that husband and wife, family members are capable of carrying out the obligation, that is, have the duty to do something. Therefore, shall_is used correctly in this article.

Another example:

Chinese text: 第三十一条 合伙人应当对出资数额、盈余分配、债务承担、入伙、退伙、合伙终止等事 项，订立书面协议。(Article 31, General Principles of Civil Law of the People’s Republic of China)

English version: Article 31 Partners shall make a written agreement covering the funds each is to provide, the distribution of profits, the responsibility for debts, the entering into and withdrawal from partnership, the ending of partnership and other such matters.

In this article, partners are the subject capable of carrying out an obligation. Shall refers to has a duty to do something. The duty of making a written agreement is imposed on the partners who can carry the duty out. This example can also support what the authors suggest.

However, in China, shall is rampant in translated English version of laws, statutes and regulations; and in many cases, it is misused. 


\section{Analyzing the Misuse of Shall in Legal English Language}

As mentioned above, it is agreed that, in legal English language, we use the same word to express the same idea and different words to express different ideas (Chen, 2011, p.63). Apparently, according to this rule, shall is a misused or abused word in legal English language, because the translator uses shall to express more than one meaning in English version of China's laws, statutes and regulations. The following are examples in which shall is misused.

\subsection{Shall is Used to Describe a Status}

For example:

a. Chinese text: 未成年人的父母是未成年人的监护人。(Article 16, General Principles of Civil Law of the People's Republic of China)

English version: The parents of a minor shall be his guardians.

b. Chinese text: 法人是具有民事权利能力和民事行为能力, 依法独立享有民事权利和承担民事义务的组 织。(Article 36, General Principles of Civil Law of the People’s Republic of China)

English version: A legal person shall be an organization that has capacity for civil rights and capacity for civil conduct and independently enjoys civil rights and assumes civil obligations in accordance with the law

c. Chinese text: 有限责任公司的股东以其认缴的出资额为限对公司承担责任; 股份有限公司的股东以 其认购的股份为限对公司承担责任。(Article 3, Company Law of the People’s Republic of China)

English version: As for a limited liability company, the shareholders shall be responsible for the company to the extent of the capital contributions they have paid. As for a joint stock limited company, the shareholders shall be responsible for the company to the extent of the shares they have subscribed for.

As the authors suggest, shall is used to impose a duty on the subject. In another word, shall is used when the subject has a duty to do something. If shall is used to describe a status in a provision, it is definitely not in the right place. In such cases, shall can be replaced by be verb, for one of the functions of be verb is to describe a status. Therefore, "The parents of a minor shall be his guardians" can be stated as "The parents of a minor are his guardians", which is much more concise.

4.2 Shall is Used to Impose an Obligation on An Object Which Is Incapable of Carrying out An Obligation

For example:

a. Chinese text: 选出或者罢免人民检察院检察长, 须报上级人民检察院检察长提请该级人民代表大会常 务委员会批准。(Article 101, the Constitution of the People's Republic of China)

English version: The election or recall of chief procurators of people's procuratorates shall be reported to the chief procurators of the people's procuratorates at the next higher level for submission to the standing committees of the people's congresses at the corresponding level for approval.

b. Chinese text: 注册商标需要改变其标志的, 应当重新提出注册申请。(Article 22, Trademark Law of the People's Republic of China)

English version: Where any word or device of a registered trademark is to be altered, a new application shall be filed.

c. Chinese text: 对于危害国家安全的犯罪分子应当附加剥夺政治权利; 对于故意杀人、强奸、放火、 爆炸、投毒、抢劫等严重破坏社会秩序的犯罪分子, 可以附加剥夺政治权利。(Article 56, Criminal Law of the People's Republic of China)

English version: Anyone who commits the crime of endangering national security shall be sentenced to deprivation of political rights as a supplementary punishment; anyone who commits the crime of seriously undermining public order by intentional homicide, rape, arson, explosion, poisoning or robbery may be sentenced to deprivation of political rights as a supplementary punishment.

Strictly speaking, shall should be preceded by a subject that can carry out the obligation so that it makes clear who has the duty to do it, and will not cause any dispute. The three subjects in the above mentioned examples are 
inanimate, and they are not the actors imposed an obligation. The authors suggest that shall should be replaced by must in such cases.

\subsection{Shall is Used to Confer a Right}

For example:

a. Chinese text: 商标注册人有权标明“注册商标”或者注册标记。(Article 9, Trademark Law of the People’s Republic of China)

English version: A trademark registrant shall have the right to indicate the wording 'Registered Trademark' or a sign indicating that it is registered.

b. Chinese text: 任何单位和个人均有权对违反本法规定逃避海关监管的行为进行举报。(Article 13, Customs Law of the People's Republic of China)

English version: All entities and individuals shall have the right to report to the Customs activities violating the provisions of this law.

c. Chinese text: 公民、法人或者其他组织认为行政机关和行政机关工作人员的具体行政行为侵犯其合法 权益, 有权依照本法向人民法院提起诉讼。(Article 2, Administrative Procedure Law of the People’s Republic of China)

English version: If a citizen, a legal person or any other organization considers that his or its lawful rights and interests have been infringed upon by a specific administrative act of an administrative organ or its personnel, he or it shall have the right to bring a suit before a people's court in accordance with this Law.

As mentioned above, shall is used to impose an obligation; therefore, it is contradictory to use shall to confer a right. When we say that a person shall have the right to do it (that is, a person has a duty to have a right), do we mean that a person has a duty or has a right? Hence, under such circumstances, be entitled to is suggested to substitute shall have the right to. It will not lead to a dispute if the provision says "a trademark registrant is entitled to indicate the wording Registered Trademark or a sign indicating that it is registered."

\subsection{Shall is Used After a Negative Word Such as Not or No}

For example:

a.Chinese text: 对任何人犯罪, 在适用法律上一律平等。不允许任何人有超越法律的特权。(Article 4, Criminal Law of the People's Republic of China)

English version: The law shall be equally applied to anyone who commits a crime. No one shall have the privilege of transcending the law.

b. Chinese text: 申请商标注册不得损害他人现有的在先权利, 也不得以不正当手段抢先注册他人已经 使用并有一定影响的商标。(Article 31, Trademark Law of the People’s Republic of China)

English version: No trademark application shall infringe upon another party's existing prior rights. Nor shall an applicant rush to register in an unfair manner a mark that is already in use by another party and that enjoys substantial influence.

c.Chinese text: 一切法律、行政法规和地方性法规都不得同宪法相抵触。(Article 5, the Constitution of the People's Republic of China)

English version: No laws or administrative or local rules and regulations may contravene the Constitution.

In the first two examples, it is intended to negate a command to do something, which means, you're not required to do it. But let's have a close check. If shall means has a duty to, then "no trademark application shall infringe upon another party's existing prior rights" is equal to "no trademark application has the duty to infringe...", which, by implication, means that you may infringe another party's prior rights if you want. This is surely not the intended meaning of the provision. The provision is meant to prohibit absolutely, to disallow. Hence, it should be no one may, which means that no person is allowed to do something, like how shall is used in the third example. 


\section{Comparing Shall with Will, Should, Must and May in Legal English Language}

Another problem is that shall is often confused with other auxiliary verbs and modal verbs, such as will, should, must and may. In addition, some scholars suggest that shall should be eliminated and replaced with other possible auxiliary verbs or modal verbs, as in some Western countries, some scholars are questioning the usage of shall in legal text and some are in favor of dropping shall out of legal language. (Li, 2007, p.60). Then, let us have a discussion of these auxiliary verbs and modal verbs, and see whether it is plausible to replace shall with them.

\subsection{Will}

Generally speaking, in English, will is used to express future tense. When used in legal English, will helps to create a promise to perform (Garner, 1995, p.941) instead of obligations. If will is used to impose an obligation on the actor as well as express future tense, it will face the same problem as shall. As pointed out by Dickerson, "the competent draftsman makes sure that each recurring word or term has been used consistently. He carefully avoids using the same word or term in more than one sense ... In brief, he always expresses the same idea in the same way and always expresses different ideas differently.” (Dickerson, 1986, p.15) Thus, will is not a plausible word to impose obligations on the capable actor.

\subsection{Should}

Like shall, should is also a modal verb, which is defined in Oxford Advanced Learner's English-Chinese Dictionary (Hornby, 2004, p.1613) as used to show what is right, appropriate, etc., especially when criticizing sb's actions. In legal English, when should is used, it means be directed to do or be recommended to do. That is to say, should is preceded by directive or suggested duties, while shall is followed by obligatory or mandatory actions. The legal language - a person shall do something is regarded as mandatory, which means, if not doing it, one will receive legal penalty or punishment; should do something, however, means if not doing it, one will take some negative consequences, but not legal punishment.

Should is misused in the following example:

Chinese text: 合格投资者必须遵守中国的法律法规和其他有关规定。(Article 4, Provisional Measures on Administration of Domestic Securities Investments of Qualified Foreign Institutional Investors)

English version: Qualified Foreign Institutional Investors should comply with laws, regulations and other relevant rules in China.

The intended meaning of this article is that QFII has a mandatory duty to comply with China's laws, thus it is suggested that shall be employed in this article, instead of should.

\subsection{Must}

In general English, must is used to state that something is necessary or very important according to Oxford Advanced Learner's English-Chinese Dictionary, (Hornby, 2004, p.1141), and there isn't much change in meanings in legal English language. Considering the misuse of shall and the controversy caused by it, some scholars suggest that must is an alternative to shall as a means of expressing obligation (Li, 2007, p.60). Another reason of abandoning shall, in favor of must, is that shall has almost disappeared from current general English, and it is just a matter of time to eliminate shall from legal English language. One way to address the problem of misuse and overuse of shall is to discipline the use of this word. That is to say, using shall only to impose an obligation on the subject capable of carrying out or performing duties. It doesn't make any sense to abandon shall from legal English considering the disappearance of this word from current general English. From another perspective, its disappearance from current general English is a positive factor of using shall only in legal English. In legal English language, shall is an essential word, and sometimes it seems as if lawyers or draftsmen are doubtful about the enforcement of laws or statutes without shall. Hence, stepping out of current general English, shall can be used only in legal English to convey the meaning of obligations. In this case, shall is much more professional than must as must sounds more informal.

\subsection{May}

Modal verb may is used in legal English language to convey the meaning that a person is allowed to do something.

For example:

Chinese text: 当事人订立合同, 有书面形式、口头形式和其他形式。(Article 10, Contract Law of the People's Republic of China)

English version: The parties may use written, oral or other forms in entering into a contract. 
It is less likely to mistranslate shall and may in legal English, except one sentence pattern - No one shall. It is understandable that no one shall pattern is actually used to convey the meaning of nobody has the right to do something, or something is not allowed by laws. However, the meaning of no one shall is contradictory to the intended meaning. In this case, may is the right word to convey the exact meaning of laws.

For example:

Chinese text: 合同当事人的法律地位平等, 一方不得将自己的意志强加给另一方。(Article 3, Contract Law of the People's Republic of China)

English version: Contracting parties shall have equal legal status, and no party may impose its will on the other party.

\section{Conclusion}

In legal English language, shall is of great importance, and is, to some extent, associated with the enforcement or effectiveness of a provision. It is not suggested that shall should be dropped from legal English language due to the important role that it has been playing in law field. Rather, disciplining the use of shall is a feasible way to address the problem of its overuse and misuse. It is suggested that shall is only used to impose an obligation on the subject that has the ability to carry it out. By doing so, the meaning of shall will be very clear and certain, and shall will not result in any dispute. Shall shall serve the legal English language as it always does.

\section{References}

Bassnett, Susan. (2004). Translation studies. Shanghai: Shanghai Foreign Language Education Press.

Bell, R. (1991). Translation and translating. London: Longman.

Chen, X. (2011). "Shall” problem and its solution in legal text. Chinese Translators Journal, 32(3), 63-67.

Chen, Z. (1992). Driving "shall” virus out of translated English legal text. Shanghai Journal of Translators For Science and Technology, 7(3), 19-20.

Dickerson, R. (1986). The fundamentals of legal drafting (2nd ed.). Boston: Little Brown.

Garner, B. A. (1995). A dictionary of modern legal usage. Oxford: Oxford University Press.

Garner, B. A. (2004). Black's law dictionary. USA: Thomson West.

Gentzler, Edwin. (1993). Contemporary translation theories. London: Routledge.

Gile, D. (1995). Basic concepts and models for interpreter and translator training. Amsterdam and Philadelphia: John Benjamins.

Hornby, A. S. (2004). Oxford advanced learner's English-Chinese dictionary. Beijing: The Commercial Press.

Jia Wenbo. (2005). On pragmatic translation with functionalist approach. Beijing: China Translation and Publishing Corporation.

Kiraly, D. (1995). Pathways to translation: pedagogy and progress. Kent, OH: Kent University Press.

$\mathrm{Li}$, K. (2007). The usage and translation of some main modal verbs in translated English legal text. Chinese Translators Journal, 28(6), 54-60.

Liao Qiyi. (2002). Exploration of contemporary western translation theories. Nanjing: Yilin Press.

Liu Yafeng. (2009). Translator's adaptation and selection - translation process research for China's global communication. Shanghai: Shanghai International Studies University.

Munday, Jeremy. (2001). Introducing translation studies: theories and applications. London: Routledge.

Newmark, P. (2001). Approaches to translation. Shanghai: Shanghai Foreign Language Education Press.

Nida, E. (2000). A fresh look at translation. In Beeby, A., D. Ensinger \& M. Presas. Investigating translation: selected papers from the 4th international congress on translation, Barcelona. Amsterdam/Philadelphia: John Benjamins Publishing Company.

Nida, E.A. (1964). Toward a science of translating. Leiden: E.J. Brill.

Pym, A. (1998). Method in translation history. Manchester: St. Jerome. 
Robinson, Dauglus. (2003). Becoming a translator: an introduction to the theory and practice of translation (2nd ed). London: Routledge.

Snell-Hornby, Mary. (2001). Translation studies: an integrated approach. Shanghai: Shanghai Foreign Language Education Press.

Toury, Gideon. (1995). Descriptive translation studies and beyond. Amsterdam: John Benjamins.

Venuti, Lawrence. (1995). The translator's invisibility: a history of translation. London: Routledge. http://dx.doi.org/10.4324/9780203360064

Wang Tao. (2001). Practical course of English-Chinese \& Chinese-English translation. Wuhan: Wuhan University Press.

Xu, J. (2009). The usage and translation of "shall" in legal English text. Theory Research, 50(11), 189.

Zhou Fangzhu. (2002). Principles of translation from English into Chinese. Hefei: Anhui University Press. 